\title{
PROBLEMATYKA REWALORYZACJI ZABYTKOWYCH WILLI W MIEJSCOWOŚCIACH UZDROWISKOWYCH NA PRZYKŁADZIE WILLI: PRIMAVERA, JAWORZYNA ORAZ WAWEL W RABCE ZDRÓJ
}

\begin{abstract}
Rabka Zdrój jest XIX-wiecznym uzdrowiskiem, położonym na pograniczu Gorców i Beskidu Wyspowego, na południu województwa małopolskiego. Jej korzenie jako osady sięgają jednak jeszcze okresu Średniowiecza, kiedy to w 1254 roku Bolesław Wstydliwy zatwierdził uposażenie klasztoru Cystersów w Szczyrzycu, które obejmowało źródła solne na terenie ludźmierskim, które można utożsamiać z późniejszą Rabką. Miejscowość stała się oficjalnie uzdrowiskiem w 1864 roku, a inicjatorem tego przedsięwzięcia był Julian Zubrzycki. Na jego terenie działały wówczas cztery źródła solanki jodowo-bromowej: „Rafaela”, „Maria”, „Krakus” oraz „Kazimierz”. W ich bliskim sąsiedztwie zlokalizowano centrum uzdrowiska, gdzie powstał m.in. Dom Zdrojowy, deptak, apteka oraz restauracja. Tutaj także zaczęto budować pierwsze pensjonaty, początkowo przeważnie drewniane, z czasem także murowane. Budynki te nosiły cechy tradycyjnej architektury Podhala, a przy tym nawiązywały do obowiązujących wówczas wzorców europejskich. Obecnie, przeważająca większość tych obiektów znajduje się w złym stanie technicznym, a sposób ich użytkowania jest przypadkowy. Istnieje więc pilna ich rewaloryzacji i adaptacji do nowych funkcji, które pozwolą na ich bieżące utrzymanie. Niniejszy artykuł prezentuje trzy projekty rewaloryzacji rabczańskich willi.
\end{abstract}

Słowa kluczowe: Rabka Zdrój, willa uzdrowiskowa, rewaloryzacja

\section{Dzieje Rabki jako uzdrowiska}

Historia Rabki jako osady sięga okresu Średniowiecza, natomiast uzdrowiskiem miejscowość ta stała się w 1864 roku, z inicjatywy Juliana Zubrzyckiego. Momentem przełomowym w historii Rabki był rok 1857 roku, kiedy Komisja Balneologiczna Krakowskiego Towarzystwa Naukowego zleciła dr Fryderykowi

\footnotetext{
${ }^{1}$ Dominika Kuśnierz-Krupa, Katedra Konserwacji Zabytków, Wydział Budownictwa i Inżynierii Środowiska, Politechnika Rzeszowska, Al. Powstańców Warszawy 12, 35-959 Rzeszów, tel. (+4817) 865 1041, email: dominikakusnierzkrupa@zeriba.pl; dkk@zeriba.pl, dkrupa@prz.edu.pl,
} 
Skrobelowi wykonanie analizy chemicznej rabczańskich wód, które okazały się mieć wyjątkowe walory lecznicze. Uzdrowisko zaczęło funkcjonować w oparciu o cztery źródła solanki jodowo-bromowej: „Rafaela”, „Maria”, „Krakus” oraz „Kazimierz”. W kolejnych latach zaczęto regulować układ urbanistyczny Rabki, wytyczając zasadnicze osie kompozycyjne założenia zdrojowego. Centrum uzdrowiska zorganizowano przy źródłach, gdzie wkrótce powstał także, dziś już nieistniejący, Dom Zdrojowy (Kurhaus), kryty deptak, budynek łazienek, a także apteka oraz restauracja z salą widowiskową. Rozwój miejscowości następował bardzo szybko. W 1867 roku w Rabce funkcjonował park zdrojowy, trzy pensjonaty parterowe, dwa domy murowane, oferujące pokoje na wynajem, sklep z towarami luksusowymi oraz stajnie dla koni kuracjuszy. W 1882 roku na zespół uzdrowiskowy składało się już 15 budynków pensjonatowych z 240 pokojami dla kuracjuszy, a także kaplica zdrojowa oraz altana przewidziana jako miejsce występów miejscowej orkiestry [1]. Drugi etap rozwoju ośrodka związany był z budową połączenia kolejowego między Rabką a Chabówką, co miało miejsce w 1885 roku i wpłynęło na poprawę dostępności miejscowości [2].

Ważnym wydarzeniem w historii uzdrowiska była zmiana jego właściciela. W 1895 roku Rabkę kupiła rodzina Kadenów, która przez kolejne dziesięć lat zarobione środki inwestowała w rozbudowę uzdrowiska, a także poprawę jego infrastruktury poprzez budowę kanalizacji, wodociągu i elektryfikację.

Początek XX wieku naznaczył się przede wszystkim budową nowego kościoła według projektu Sławomira Odrzywolskiego. Okres międzywojenny przyniósł kolejne zmiany w urbanistyce i architekturze uzdrowiska. Zmiany te były podporządkowane zaleceniom planu regulacyjnego, jaki sporządzono w Ministerstwie Zdrowia Publicznego. Centrum uzdrowiska zaczęło krystalizować się wzdłuż ulicy Orkana, a jego rozwój postępował w kierunku północno-wschodnim. Wówczas to zmienił się także nieco charakter rabczańskiej architektury z inspirowanej stylem „Alpejskim” na modernizm [3].

Większość drewnianej architektury Rabki z początku XX wieku wyburzono w 1975 roku, co do dzisiaj jest ogromną stratą dla krajobrazu kulturowego uzdrowiska.

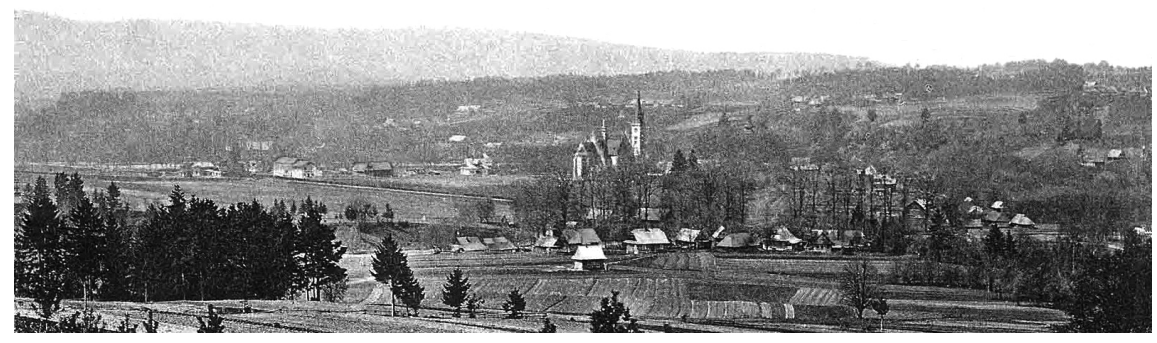

Rys.1. Widok na Rabkę od strony północno-wschodniej w 1 połowie XX wieku, na dawnej pocztówce, [w] Archiwum autorki

Fig.1. View of Rabka from the north-east in the first half of the 20th century, on the old post-card, [in:] the Authors' Archive 


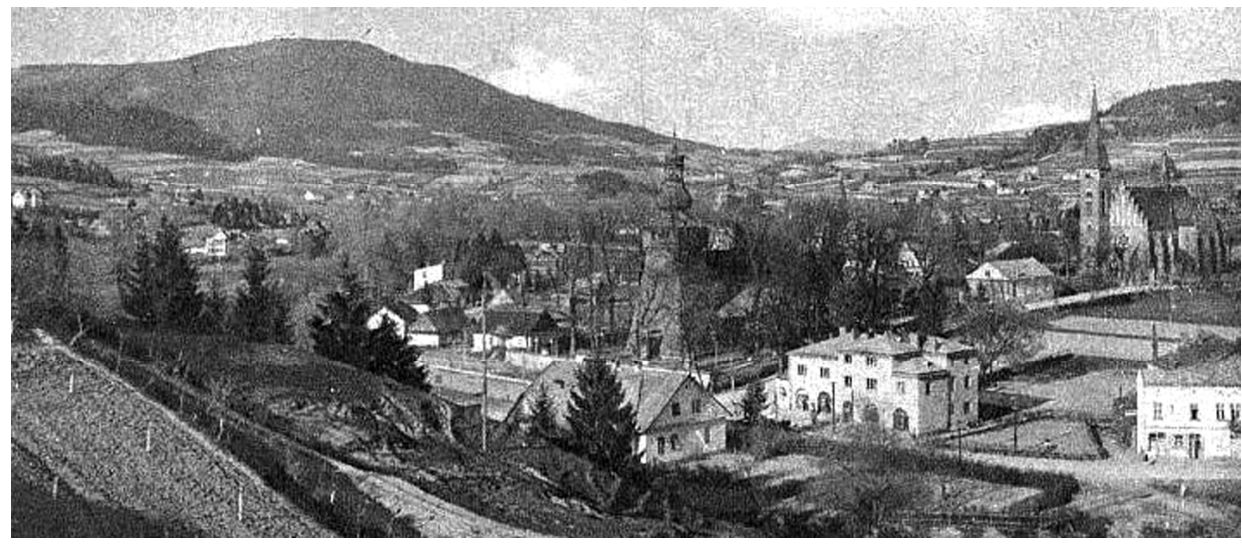

Rys.2. Widok na Rabkę od strony południowo-zachodniej w 1 połowie XX wieku, na dawnej pocztówce, [w] Archiwum autorki

Fig.2. View of Rabka from the south-west in the first half of the 20th century, on the old postcard, [in:] the Authors' Archive

\section{Zabytkowe wille Rabki - historia i współczesność}

W rozwoju architektury uzdrowiskowej Rabki z XIX i 1 połowy XX wieku można wyodrębnić trzy etapy. Budynki zaprojektowane i wzniesione w pierwszym okresie powstania miejscowości wyraźnie nawiązują do wzorców klasycystycznych, które tak chętnie stosowane były przez architektów w 1 połowie XIX wieku. Jako przykłady reprezentatywne dla tej grupy należy wymienić wille: „Pod Trzema Różami” oraz „Luboń”, położone przy ul. Parkowej. Obiekty te posiadają kolumnowe portyki zaprojektowane na osi elewacji frontowych, które ewidentnie nawiązują do architektury klasycznej. Natomiast ich bryły, nakryte dwuspadowymi dachami o połaciach wysuniętych przed lico szczytów przywołują wspomnienie ówczesnej architektury „,szwajcarskiej” lub „tyrolskiej”. Etap drugi rozwoju architektury uzdrowiskowej w Rabce dotyczy obiektów powstałych pod koniec XIX wieku. W okresie tym można wyodrębnić kilka typów rozwiązań w zakresie architektury pensjonatowej, jednak najczęściej spotykanym jest typ bazujący na połączeniu cech stylu ,alpejskiego” z eklektyzmem, reprezentowany przez takie obiekty jak willa „Kazimierz”, ”Warszawa”, „Scholastyka, „Pod Aniołem” czy „Korona”. Typ ten cechował się ponadto zwartym rzutem bryły, dachem dwuspadowym z osiowo zlokalizowanymi facjatami i gankami zdobionymi bogatym detalem snycerskim. Etap trzeci w rozwoju budownictwa pensjonatów Rabki związany był z pojawienie się w ich architekturze elementów stylu zakopiańskiego, co miało miejsce na początku XX wieku. Jako przykłady realizacji willi powstałych $\mathrm{w}$ tym okresie można wymienić budynek kolonii szpitala dziecięcego św. Ludwika oraz willę Wierchy. Opisane wyżej wille były w przeważającej większości obiektami drewnianymi. Architektura murowana 
pojawiła się w uzdrowisku w okresie międzywojennym. Modernistyczne wille i pensjonaty zaczęto budowa wzdłuż ul. Orkana (wille „Biały dworek”, „Świt”, „Łowiczanka”), a także na stokach Bani (m.in. willa Primavera) [4].

\section{Willa „Primavera”}

Willa „Primavera” została wzniesiona w latach 1926-27 w stylu modernistycznym i jest jednym z najciekawszych rabczańskich obiektów zrealizowanych w tej estetyce. Wille zbudowano na południowych stokach góry Bani według projektu architektów Maksymiliana Burstina i Jerzego Struszkiewicza (zaprojektowali oni także m.in. budynek kliniki położniczej w Krakowie przy ul. Kopernika 23). Zabytkowa willa do dzisiaj odznacza się atrakcyjną bryłę o wysmakowanych proporcjach, która wpisuje się w krajobraz kulturowy modernistycznej Rabki, nawiązując jednocześnie do europejskich trendów w architekturze 1 połowy XX wieku. Obiekt pierwotnie funkcjonował jako pensjonat, później pełnił funkcję ośrodka zdrowia. Przez ostanie lata willa była nieużytkowana w związku z czym podupadła. Z czasem zatraciła dawny urok i charakter pensjonatu uzdrowiskowego.

Obecny inwestor - organ administracji samorządowej - postanowił odnowić budynek i przystosować do wymagań obowiązujących przepisów w zakresie funkcji centrum oświatowo- kulturalnego. Willa nie jest wpisana do Rejestru Zabytków, jest jednak ujęta w Gminnej Ewidencji Zabytków, a co za tym idzie wszelkie zamierzenia budowlane należy uzgadniać w Wojewódzkim Konserwatorem Zabytków (Delegatura w Nowym Targu).

Willa „Primavera” jest budynkiem 4 - kondygnacyjnym, wzniesionym w technologii tradycyjnej - murowanej. Ściany kondygnacji nadziemnych i piwnic wykonano z cegły pełnej, a następnie obustronnie otynkowano. Budynek

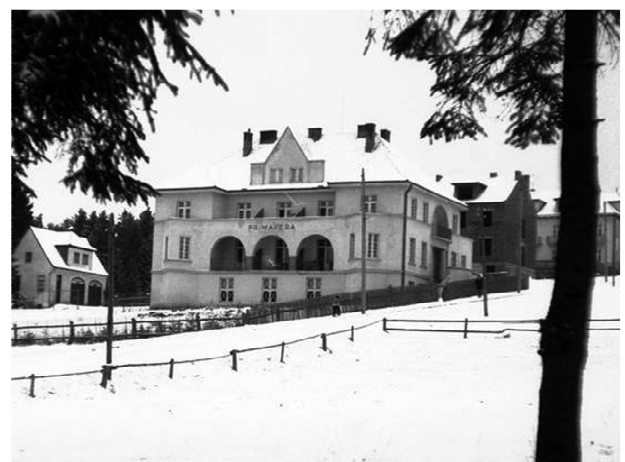

Rys.3. Willa „Primavera” w 1 połowie XX wie$\mathrm{ku}$, widok od strony południowo-wschodniej, na dawnej pocztówce, [w] Archiwum autorki

Fig.3. Pension "Primavera" in the first half of the 20th century from the south-east, on the old postcard, [in:] the Authors' Archive

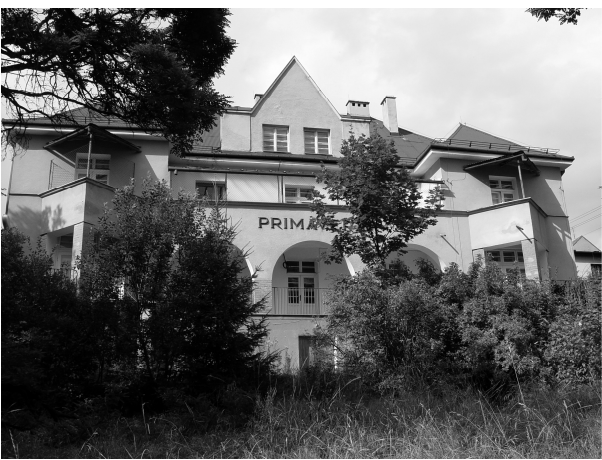

Rys.4. Willa „Primavera” w 2008 roku, przed przystąpieniem do prac projektowych. Widok od strony południowej. Fot. D. Kuśnierz-Krupa, 2008

Fig.4. Pension "Primavera" in 2008, before designing process. View from the south. Photo by D. Kuśnierz-Krupa 2008 
posiada stropy gęstożebrowe. Dach willi wykonano w konstrukcji drewnianej i pokryto blachą. Przed przystąpieniem do opracowania projektu architektoniczno-budowlanego wykonano inwentaryzację obiektu oraz ekspertyzę konstrukcyjną jego stanu technicznego. Ekspertyza ta określiła, że elementy konstrukcyjne budynku nie zdradzają poważniejszych uszkodzeń ani śladów zużycia. Jedynie tarasy i słupy na parterze od strony południowej oraz ściany zewnętrzne pomieszczeń znajdujących się pod nimi na skutek ciągłego zamakania (związanego z brakiem zabezpieczenia) były w gorszym stanie.

Projekt rewaloryzacji willi polega na przywróceniu jej dawnej świetności oraz, jak wspominano wyżej, adaptacji do nowej funkcji kulturalno - oświatowej. W obiekcie zaprojektowano sale konferencyjne, warsztatowe, pracownie oraz sale seminaryjne. Kondygnacja piwnic przeznaczona została na funkcje pomocnicze i techniczne (m. in. kotłownię). Na parterze zaplanowano biura, gabinety oraz sale konferencyjne i seminaryjne. Tutaj zaprojektowano również pomieszczenie socjalne dla pracowników centrum. Układ pomieszczeń piętra został podporządkowany funkcji obiektu i zaplanowano w nim sale dydaktyczne oraz gabinety do pracy indywidualnej. Poddasze willi zaadoptowano na przestrzeń pomocniczą [5].

Realizacja projektu nastąpi najprawdopodobniej w ciągu 2 lat. Należy mieć nadzieję, że dzięki zaplanowanym pracom rewaloryzacyjnym willa „Primavera” odzyska dawną świetność.

\section{Willa ,Jaworzyna"}

Willa „Jaworzyna” w Rabce-Zdroju położona jest przy dzisiejszej Al. Jana Pawła II (wcześniej ul. Piłsudzkiego). Jest obiektem 4-kondygnacyjnym o ciekawej formie i charakterystycznym dla Rabki detalu architektonicznym. Obiekt powstał zapewne na przełomie XIX i XX wieku jako duży pensjonat. W przeszłości pełnił funkcje internatu św. Benedykta, prowadzonego przez OO. Benedyktynów, później był siedzibą Sanatoryjnego Gimnazjum Żeńskiego p.w. św. Tereski. Około połowy XX wieku do willi „Jaworzyna” przeniesiono Sanatoryjne Gimnazjum Męskie Dra Jana Wieczorkowskiego, założone w 1924 roku. Gimnazjum to oprócz działalności edukacyjnej zapewniało młodzieży kuracje w sanatorium, a także opiekę lekarską. Obecnie w willi „Jaworzyna” działa rabczańskie Liceum Ogólnokształcące im. E. Romera.

Opiekunem obiektu z urzędu jest organ administracji samorządowej, który około 8 lat temu postanowił odnowić budynek. Willa nie jest ujęta w rejestrze zabytków nieruchomych województwa, ani w gminnej ewidencji. Jest natomiast położona w strefie ochrony konserwatorskiej uzdrowiska i z tego tytułu wszelkie prace modernizacyjne przy obiekcie muszą być konsultowane z Wojewódzkim Konserwatorem Zabytków (Delegatura w Nowym Targu).

Prace rewaloryzacyjne w willi Jaworzyna polegały na modernizacji elewacji oraz odczyszczeniu i uzupełnieniu detali architektonicznych: zabytkowej snycerki, gzymsów oraz drewnianych dekoracji przy lukarnach [6]. 
Inwestycja została zakończona w 2008 roku. Kilka lat później obok willi wzniesiono nowy budynek dydaktyczny liceum im. E. Romera, który w swej formie miał nawiązywać do historycznego obiektu.

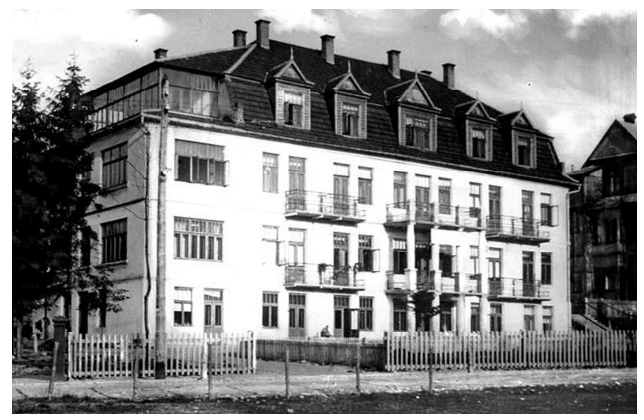

Rys.5. Willa „Jaworzyna” w 1 połowie XX wieku. Widok od strony południowo-zachodniej. Pocztówka [w:] Archiwum autorki

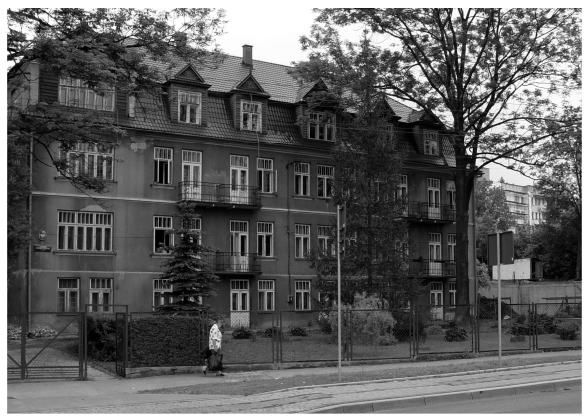

Rys.6. Willa „Jaworzyna” w 2007 roku, przed rewaloryzacją. Fot. D. KuśnierzKrupa 2007

Fig.6. Pension "Jaworzyna" in 2007, before revalorization. Photo by D. Kuśnierz-Krupa 2007

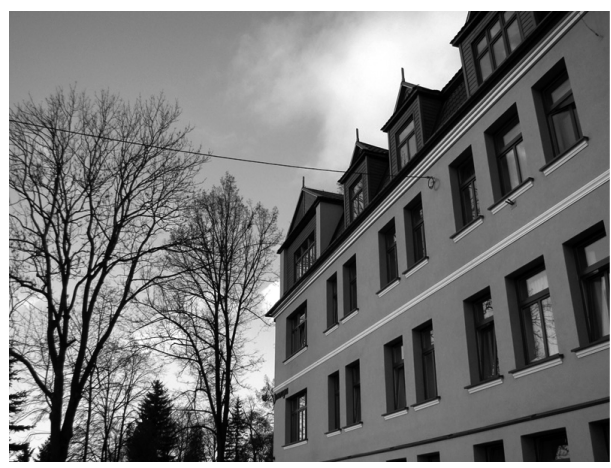

Rys.8. Willa „Jaworzyna” obecnie, po rewaloryzacji. Widok na fragment elewacji frontowej. Fot. D. Kuśnierz-Krupa 2013

Fig.8. Pension "Jaworzyna" nowadays, after revalorization. View of front elevation fragment. Photo by D. Kuśnierz-Krupa 2013

\section{Willa ,Wawel”}

Ostatnim z prezentowanych obiektów jest obecnie nieużytkowana willa „Wawel”, położona w samym sercu uzdrowiska, przy głównej ulicy - Al. Jana Pawła II. Obiekt został zbudowany na początku wieku XX jako pensjonat zwią- 
zany z funkcją uzdrowiskową Rabki. Znajdowały się w nim pokoje dla kuracjuszy, cześć wspólna (świetlica wraz z jadalnią) oraz zaplecze techniczne. Po II wojnie światowej, po latach prosperity pensjonat zaczął podupadać. Jego stan techniczny znacznie się pogorszył w okresie kiedy jego użytkownikiem była szkoła podstawowa. Po jej likwidacji w pierwszych latach XXI wieku obiekt był nieużytkowany przez kilka lat, aż do momentu, kiedy w 2010 roku pojawił się inwestor prywatny, który kupił go od władz samorządu terytorialnego.

Willa „Wawel” jest obiektem piętrowym z użytkowanym poddaszem. Jest też częściowo podpiwniczona. Układ konstrukcyjny budynku jest mieszany. Willa posiada drewnianą więźbę o konstrukcji płatwiowo-krokwiowej, na której wspiera się stromy, 2-spadowy dach, obecnie pokryty blachą trapezową, która zastąpiła tradycyjny gont. Budynek został wzniesiony w technologii tradycyjnej drewnianej ze ścianami wieńcowymi z bali drewnianych. Posiada stropy belkowe, drewniane. $\mathrm{W}$ części podpiwniczonej ściany wykonano jako murowane $\mathrm{z}$ kamienia łamanego, podobnie fundamenty.

Nowy właściciel obiektu postanowił przystąpić do remontu konserwatorskiego willi. W tym celu opracowano projekt architektoniczno-budowany uwzględniający adaptację willi do nowej funkcję - Domu Pogodnej Jesieni. Działanie to nie będzie wymagało zmian jego obrysu, ani zewnętrznych proporcji. Ze względu na niezaprzeczalne walory architektoniczne pensjonatu, adaptacja będzie polegała przede wszystkim na przystosowaniu układu funkcjonalno przestrzennego do wybranej funkcji z bardzo zachowawczym podejściem do elewacji budynku i zastosowanych w niej materiałów.

Budynek nie jest wpisany do rejestru zabytków nieruchomych województwa małopolskiego, jest jednak ujęty w gminnej ewidencji zabytków, co jest jednoznaczne z zaopiniowaniem inwestycji przez Wojewódzkiego Konserwatora Zabytków (Delegatura w Nowym Targu). W trakcie konsultacji i wizji lokalnych określił on granice adaptacji projektu i wytyczne konserwatorskie.

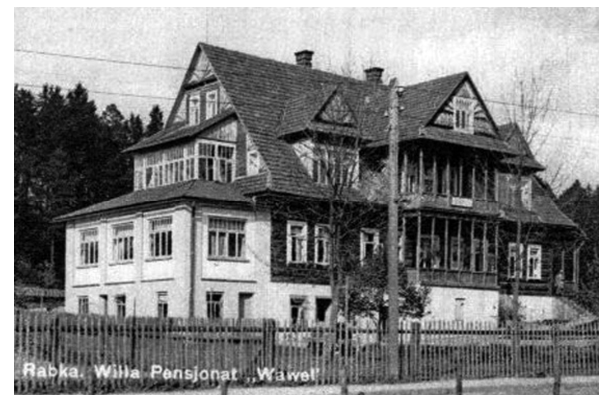

Rys.9. Willa „Wawel” w 1 połowie XX wie$\mathrm{ku}$. Widok od strony południowo-zachodniej. Pocztówka [w:] Archiwum autorki

Fig.9. Pension "Wawel" in the first half of the 20th century. View from the south-west. Postcard [in:] the Authors' Archive

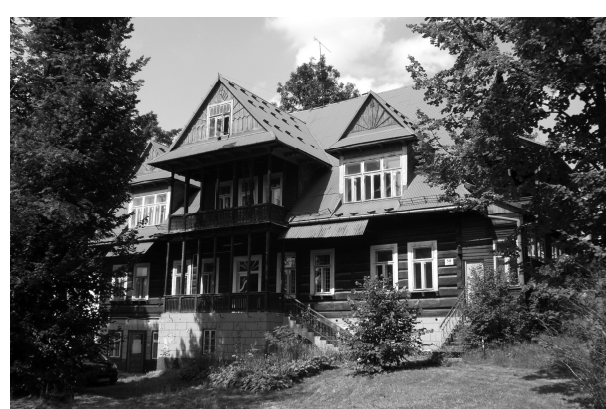

Rys.10. Willa „Wawel” w 2011 roku, przed rewaloryzacją. Fot. D. Kuśnierz-Krupa 2011

Fig.10. Pension "Wawel" in 2011, before revalorization. Photo by D. Kuśnierz-Krupa 2011 
Willa jest obiektem drewnianym, zatem przed przystąpieniem do projektu niezbędna była ekspertyza techniczna stanu jego konstrukcji oraz budulca. Poprzedziła ją inwentaryzacja konstrukcji oraz wizje lokalne w terenie. Ekspertyza wykazała, iż obiekt znajduje się w bardzo złym stanie technicznym. Opinia ta dotyczyła fundamentów, ścian wewnętrznych i zewnętrznych wszystkich kondygnacji, drewnianych stropów oraz konstrukcji dachu. Zawarte w niej ustalenia pociągnęly za sobą konieczność przeprojektowania struktury budynku. Postanowiono wymienić całą substancję, która nie nadawał się do dalszej eksploatacji. Zostanie ona zastąpiona identycznymi elementami konstrukcyjnymi (belki stropowe, elementy nośne ścian wewnętrznych, schody, bale, z których wykonane były ściany zewnętrze) oraz dekoracyjnymi (elementy snycerskie). $\mathrm{W}$ celu przeprowadzenia przedmiotowego zamierzenia konserwatorskiego konieczne okazało częściowe rozebranie obiektu, a następnie złożenie go ponowne z częściowym wykorzystaniem nowych elementów konstrukcyjnych oraz materiałów budowlanych.

Willa, jak wspomniano wcześniej, będzie pełniła funkcję Domu Pogodnej Jesieni, natomiast $\mathrm{w}$ jej przyziemiu (o powierzchni $348,15 \mathrm{~m}^{2}$ ) zaprojektowano lokal usługowy wraz z zapleczem magazynowym i gospodarczym. Parter (o powierzchni $321,10 \mathrm{~m}^{2}$ ), piętro (o powierzchni $244,98 \mathrm{~m}^{2}$ ) i poddasze (o powierzchni $156,86 \mathrm{~m}^{2}$ ) pensjonatu przeznaczono na potrzeby funkcji wiodącej [7].

Projekt zakłada odtworzenie wszystkich detali i elementów dekoracyjnych obiektu, które uległy destrukcji. Przewiduje także wymianę zabytkowej stolarki na drewnianą o identycznych podziałach i wielkości profili. Realizację inwestycji przewiduje się na lata 2014-2015.

\section{Podsumowanie}

Opisane wyżej projekty konserwatorskie realizowane w jednym z najpiękniejszych polskich uzdrowisk Rabce-Zdroju były wyzwaniem projektowym zarówno dla ich właścicieli jak i architektów. Wymagały pogodzenia sztuki konserwatorskiej, ekonomicznych możliwości ich właścicieli oraz wizji projektantów. Należy mieć nadzieję, że wille te, po kompleksowo i prawidłowo przeprowadzonych pracach konserwatorskich na powrót będę stanowić atrakcyjny element dziedzictwa kulturowego Rabki.

\section{Literatura}

[1] Beiersdorf Z., Krasnowolski B.: Rabka. Studialne materiały konserwatorskie dla zespołu uzdrowiska i dawnej wsi, mpis, Kraków 1977, [w:] Archiwum NID O. Kraków, sygn. 495, s. 4-6.

[2] Kowalczyk K., Moskal G., Rapta M., Szlaga J.: Rabka Juliana Zubrzyckiego, Wyd. Zachylina, Rabka 2012, s. 139. 
[3] Beiersdorf Z., Krasnowolski B.: Rozwój przestrzenny i architektura Rabki, „Teka Komisji Urbanistyki i Architektur", t. XVI, 1982, Wyd. PAN, O. Kraków, s. 127-128.

[4] Ibidem, s. 131-132 oraz Słownik geograficzny Królestwa Polskiego i innych krajów słowiańskich, B. Chlebowski (red.), Wyd. Nakł. W. Walewskiego, Warszawa 1892, t. IX, s. 343-347.

[5] Projekt architektoniczno-budowlany rewaloryzacji willi „Primavera”, opr. Grupa Projektowa ZERIBA, D. Kuśnierz-Krupa, M. Krupa, Ł. Wesołowski, 2008.

[6] Projekt architektoniczno-budowlany modernizacji willi „Jaworzyna” - budynku L.O. im. E. Romera, opr. Grupa Projektowa ZERIBA, D. Kuśnierz-Krupa, M. Krupa, Ł. Wesołowski, 2007.

[7] Projekt architektoniczno rewaloryzacji i adaptacji willi „Wawel”, opr. Grupa Projektowa ZERIBA, D. Kuśnierz-Krupa, M. Krupa, Ł. Wesołowski, 2013-2014.

\section{ISSUES OF REVALORIZATION OF HISTORIC PENSIONS IN HEALTH-RESORTS ON THE EXAMPLE "PRIMAVERA", “JAWORZYNA" AND "WAWEL" PENSIONS IN RABKA ZDROJ}

\section{S u m m a r y}

Rabka Zdrój is a 19th-century health resort located between two mountain ranges: the Gorce and the Beskid Wyspowy, in the south of the Lesser Poland Voivodeship. Its origins as a settlement date back to the Middle Ages when, in 1254, king Bolesław Wstydliwy granted the endowment for the Cistercian Monastery in Szczyrzyc, which included salt springs in the vicinity of Ludźmierz that might later be identified as Rabka. The place officially became a health resort in 1864 and the author of the idea was Julian Zubrzycki. Four springs of iodine-bromine brine named: "Rafaela", "Maria", "Krakus" and "Kazimierz" functioned in the resort. The centre of the health resort in which there were Spa House, a promenade, a chemist's and a restaurant was located in their close neighbourhood. It was here that the first pensions were built, initially mostly wooden, later masonry. These buildings had features characteristic for traditional architecture of the Podhale region, while at the same time alluding to the current European models. The state of preservation of the majority of these pensions is poor, and their use is incidental. There is an urgent need for their revalorization and adaptation to new functions which will allow for their maintenance. This article presents three revalorization projects of the Rabka pensions.

Keywords: Rabka Zdroj, health-resort pension, revalorization

Przestano do redakcji: 19.02.2015 $r$.

Przyjęto do druku: 22.06.2015 r.

DOI: $10.7862 / \mathrm{rb} .2015 .56$ 